Article

\title{
Hardness and Indentation Fracture Toughness of Slip Cast Alumina and Alumina-Zirconia Ceramics
}

\author{
Irena Žmak ${ }^{1}$, Danko Ćorić ${ }^{1, *}$, Vilko Mandić $^{2}$ (D) and Lidija Ćurković $^{1}$ \\ 1 Department of Materials, Faculty of Mechanical Engineering and Naval Architecture, University of Zagreb, \\ HR-10000 Zagreb, Croatia; irena.zmak@fsb.hr (I.Ž.); lidija.curkovic@fsb.hr (L.Ć.) \\ 2 Department of Inorganic Chemical Technology and Non-Metals, Faculty of Chemical Engineering and \\ Technology, University of Zagreb, Marulićev trg 20, 10000 Zagreb, Croatia; vmandic@fkit.hr \\ * Correspondence: danko.coric@fsb.hr; Tel.: +385-98-137-9401
}

Received: 1 October 2019; Accepted: 23 December 2019; Published: 26 December 2019

check for updates

\begin{abstract}
Alumina $\left(\mathrm{Al}_{2} \mathrm{O}_{3}\right)$ and zirconia $\left(\mathrm{ZrO}_{2}\right)$ have good overall properties and thus are widely used oxide technical ceramics. The biggest drawback of $\mathrm{Al}_{2} \mathrm{O}_{3}$ is its low fracture toughness. In contrast, $\mathrm{ZrO}_{2}$ is relatively tough, but is also much more expensive. In order to improve the alumina toughness, composite ceramics are being developed. Slip casting technology has economic advantages over the conventional hot isostatic pressure technology, but problems may arise when preparing stable highly-concentrated suspensions (slip) for filling the mold. The purpose of this study is to prepare aqueous suspensions using 70 wt. $\% \alpha-\mathrm{Al}_{2} \mathrm{O}_{3}$, with $0,1,5$ and 10 wt. $\%$ of added $t-\mathrm{ZrO}_{2}$. Suspensions were electrosterically stabilized using the ammonium salt of polymethylacrylic acid, an alkali-free anionic polyelectrolyte dispersant. Also, magnesium oxide in form of magnesium aluminate spinel $\left(\mathrm{MgAl}_{2} \mathrm{O}_{4}\right)$ was used to inhibit the abnormal alumina grain growth during the sintering process. Minimum viscosities were used as stability estimators, where an increase in $\mathrm{ZrO}_{2}$ content required adding more dispersant. After sintering, the Vickers indentation test was used to determine the hardness and the indentation fracture toughness from the measurement of the crack length. Also, the brittleness index $\left(B_{\mathrm{i}}, \mu \mathrm{m}^{-1 / 2}\right)$ was calculated from values of Vickers hardness and the Vickers indentation fracture toughness. It was found that with increasing $\mathrm{ZrO}_{2}$ content the fracture toughness increased, while the hardness as well as the brittleness index decreased. Zirconia loading reduces the crystallite sizes of alumina, as confirmed by the X-ray diffraction analysis. SEM/EDS analysis showed that $\mathrm{ZrO}_{2}$ grains are distributed in the $\mathrm{Al}_{2} \mathrm{O}_{3}$ matrix, forming some agglomerates of $\mathrm{ZrO}_{2}$ and some pores, with $\mathrm{ZrO}_{2}$ having a smaller grain size than $\mathrm{Al}_{2} \mathrm{O}_{3}$.
\end{abstract}

Keywords: alumina; zirconia; slip casting; Vickers hardness; fracture toughness

\section{Introduction}

Aluminum oxide $\left(\mathrm{Al}_{2} \mathrm{O}_{3}\right)$ is the most important technical material of the oxide ceramics group, suitable for various applications in the electrical, electronic, chemical and medical industries. Densely sintered $\mathrm{Al}_{2} \mathrm{O}_{3}$ ceramic is characterized by low fracture toughness and high hardness, temperature stability, good wear resistance, corrosion resistance at elevated temperatures and excellent biocompatibility. A major demerit of aluminum oxide is its pronounced brittleness, that is, its relatively low fracture toughness which is $4-6 \mathrm{MPa} \mathrm{m}^{\frac{1}{2}}$. After the start of cracking, its propagation does not stop by plastic deformation, but continues until fracture. This phenomenon is usually caused by individual defects on the surface or very close to the surface of the material, since it is the site of greatest stress [1-3].

Pure zirconium oxide $\left(\mathrm{ZrO}_{2}\right)$ also belongs in the oxide ceramics group. It has almost ideal properties: high fracture toughness (up to $15 \mathrm{MPa}^{\frac{1}{2}}$ ), high flexural and tensile strength, high wear 
resistance and corrosion resistance, low thermal conductivity, good thermal shock resistance, resistance to high temperatures and excellent biocompatibility [3,4].

Pure $\mathrm{ZrO}_{2}$ occurs in three polymorphic modifications: monoclinal, $m$ (from room temperature up to $\left.1170{ }^{\circ} \mathrm{C}\right)$, tetragonal, $t\left(1170{ }^{\circ} \mathrm{C}-2370{ }^{\circ} \mathrm{C}\right)$ and cubical, $c$ (from $2370^{\circ} \mathrm{C}$ to melting point). During cooling, the transition from tetragonal to monoclinic phase takes place at a temperature of about $100{ }^{\circ} \mathrm{C}$ below $1170{ }^{\circ} \mathrm{C}$, whereby the volume increases by 3-5\%. Because of the stress resulting from the phase transformation, while cooling from sintering temperature $\left(1500-1700^{\circ} \mathrm{C}\right)$, cracking occurs in the final product. To avoid phase transitions and thus cracking, $\mathrm{ZrO}_{2}$ is stabilized by the addition of metal oxides $\left(\mathrm{CaO}, \mathrm{CeO}_{2}, \mathrm{MgO}, \mathrm{Y}_{2} \mathrm{O}_{3}\right)[4]$.

By mixing ceramic powders in the initial phase of forming it is possible to produce $\mathrm{Al}_{2} \mathrm{O}_{3}-\mathrm{ZrO}_{2}$ composite ceramics, which exhibit better properties compared to monolithic $\mathrm{Al}_{2} \mathrm{O}_{3}$, respectively $\mathrm{ZrO}_{2}$ ceramics. Since the addition of $\mathrm{ZrO}_{2}$ increases the fracture toughness of $\mathrm{Al}_{2} \mathrm{O}_{3}$ ceramics, such composite ceramics are referred to as zirconia toughened alumina-ZTA in literature [5,6]. Stress that occurs under increased strain conditions can cause cracks in the ceramic material. In case of $\mathrm{Al}_{2} \mathrm{O}_{3}-\mathrm{ZrO}_{2}$ ceramic, crack formation is mitigated on behalf of a phase transition. Namely, $\mathrm{ZrO}_{2}$ grains that are found in the cracking zone undergo phase transformation from tetragonal into monoclinic phase, where the corresponding volume change facilitates closure of the cracks and prevents further propagation. These favorable mechanical and tribological properties of $\mathrm{Al}_{2} \mathrm{O}_{3}-\mathrm{ZrO}_{2}$ composite ceramics make it suitable for use in many areas, including cutting tools and implants. $\mathrm{Al}_{2} \mathrm{O}_{3}-\mathrm{ZrO}_{2}$ is a perspective biomaterial also, since, apart from biocompatibility and mechanical properties, it also meets the aesthetic criteria [5-9].

Contemporary trends in material development focus on improving the properties of existing materials as well as developing new ones. In order to lower their production costs and make them more environmentally friendly, the interest in the production of technical ceramics by slip casting has increased in the last few years. This technology is inexpensive, simple, fast, environmentally friendly and flexible. It enables production of ceramic products of different sizes and form complexities but requires an adequate understanding of colloidal solutions in order to optimize process parameters for the final ceramic product to have the required mechanical and other properties [10].

The properties of ceramic products obtained by slip casting depend on particle size of the ceramic powders and their proportion in the suspension. Generally, smaller particles and higher suspension concentration ultimately result in better properties. However, high suspension concentrations and particle diameter less than $1 \mathrm{~mm}$ cause enhanced interactions between particles, which significantly increases viscosity and makes it difficult to cast the suspension into a gypsum mold [3,10-12].

Many studies are focused on observing the influence of certain kinds and amounts of additives on the viscosity of ceramic suspensions and consequent properties of the final ceramic product [13-18].

For reasons mentioned above, highly concentrated suspensions are stabilized by addition of various additives (dispersants). The difference between the ceramic product obtained by casting a stable and an unstable suspension is best illustrated in Figure 1. If an unstable suspension containing irregular aggregates of particles (agglomerates) is poured into a mold, the particles are arranged into an irregular structure when dry (draining of water into mold walls), leaving cavities (voids) and irregularities in the microstructure of the raw material (Figure 1a). By sintering, these irregularities are further enhanced, resulting in a ceramic product of unsatisfactory properties. If the suspension is stable, by drying the particles become densely arranged, which after sintering gives a ceramic product of the appropriate mechanical and other properties (Figure 1b).

Agglomeration and sedimentation should be prevented by enhancing the rejection forces between particles of the ceramic powder. These forces must be strong enough to overcome the attractive, van der Waals force [7].

These interaction can be controlled with chemical additives in three different ways: electrostatic, steric, and electrosteric (a combination of the first two) stabilization. The influence of additives (different dispersants) on the ceramic suspension stability has been extensively researched [13-19]. 


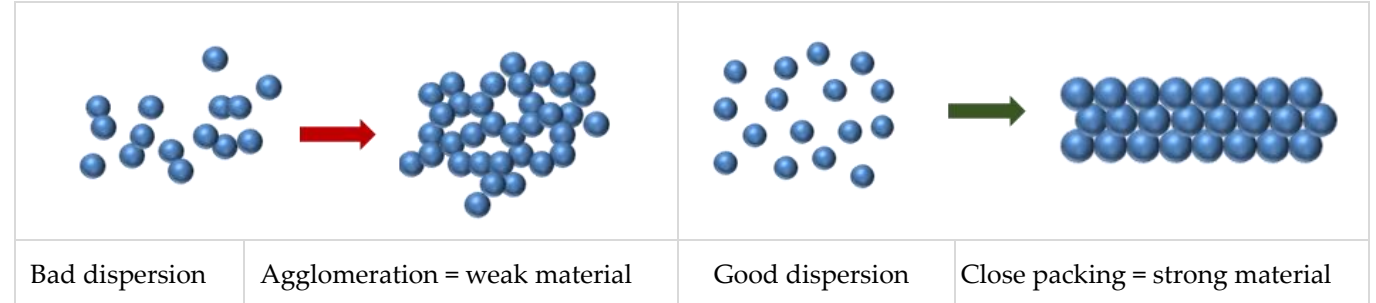

(a)

(b)

Figure 1. The influence of particle dispersion on properties on sintered ceramics: (a) bad dispersion and (b) good dispersion

Some of the dispersants which have been used as stabilizing agents for preparation of stable aqueous alumina suspension include ammonium polymethacrylate ("Darvan C") [19-21], 4,5-dihydroxy-1,3-benzenedisulfonic acid disodium salt ("Tiron") [21-23], triammonium salt of aurintricarboxylic acid ("Aluminon") [21], (Darvan C-N) [23], sodium pyrophosphate, diammonium hydrogen citrate [24], citric acid [23], ammonium polyacrylate ("Seruna D-305") [25], carbonic acid salt ("Dolapix CE 64") [20,26,27], polycarbonic acid salt ("Dolapix PC 33") and carbonic acid ester ("Dolapix ET 85") [27].

The stability of the suspension is tested by sedimentation tests, by measuring the zeta potential and the particle size in the suspension and by determining rheological parameters [6,8]. The goal of the presented study was the preparation of stable $\mathrm{Al}_{2} \mathrm{O}_{3}$ and $\mathrm{Al}_{2} \mathrm{O}_{3}-\mathrm{ZrO}_{2}$ suspension by electrosteric stabilization suitable for slip casting. In addition, the main interest of this research is the effect of $\mathrm{ZrO}_{2}$ content $(0,1,5$ and $10 \mathrm{wt}$. \%) on the microstructure and mechanical properties (hardness, fracture toughness and brittleness index) of sintered $\mathrm{Al}_{2} \mathrm{O}_{3}-\mathrm{ZrO}_{2}$ composite ceramics.

\section{Materials and Methods}

\subsection{Ceramic Powder and Reagents}

Samples of monolithic $\mathrm{Al}_{2} \mathrm{O}_{3}$ and composite $\mathrm{Al}_{2} \mathrm{O}_{3}-\mathrm{ZrO}_{2}$ were prepared by the slip casting technique. For preparation of highly concentrated aqueous suspensions (slips) following components were used:

- High-purity $\mathrm{Al}_{2} \mathrm{O}_{3}$, with average particle size of 300-400 nm (Alcan Chemicals, Stamford, CT, USA)

- High-purity $\mathrm{ZrO}_{2}$ stabilized with $3 \mathrm{~mol} \%$ of yttria $\left(\mathrm{Y}_{2} \mathrm{O}_{3}\right)$, with average particle size of $25 \mathrm{~nm}$ (SkySpring Nanomaterials Inc., Houston, TX, USA)

- An alkali-free anionic polyelectrolyte dispersant Dolapix CE 64 (Zschimmer \& Schwarz GmbH \&Co KG Chemische Fabriken, Lahnstein, Germany)-70 wt. \% aqueous solution of the ammonium salt of polymethacrylic acid (PMAA- $\mathrm{NH}_{4}$ )

- Magnesium oxide added as magnesium aluminate spinel $\left(\mathrm{MgAl}_{2} \mathrm{O}_{4}\right)$ made by Alfa Aesar, Haverhill, MA, USA was used to inhibit the abnormal alumina grain growth during the sintering process [22]. Magnesium spinel is segregated on the grain boundaries of alumina grains and reducing the mobility of the grain boundaries

- $\quad$ Deionized water

Chemical composition of the $\mathrm{Al}_{2} \mathrm{O}_{3}$ and $\mathrm{ZrO}_{2}$ powders, according to the manufacturer's data, is given in Tables 1 and 2, respectively.

Table 1. Chemical composition of $\mathrm{Al}_{2} \mathrm{O}_{3}$ powder.

\begin{tabular}{ccccccc}
\hline Component & $\mathrm{MgO}$ & $\mathrm{Fe}_{2} \mathrm{O}_{3}$ & $\mathrm{SiO}_{2}$ & $\mathrm{Na}_{2} \mathrm{O}$ & $\mathrm{CaO}$ & $\mathrm{Al}_{2} \mathbf{O}_{3}$ \\
\hline wt. $\%$ & 0.066 & 0.015 & 0.02 & 0.05 & 0.013 & balance \\
\hline
\end{tabular}


Table 2. Chemical composition of the $\mathrm{ZrO}_{2}$ powder.

\begin{tabular}{ccc}
\hline Component & $\mathrm{Y}_{2} \mathrm{O}_{3}$ & $\mathrm{ZrO}_{2}$ \\
\hline mol. $\%$ & 3 & 97 \\
\hline
\end{tabular}

In the present study, powder X-ray diffraction (PXRD) analysis was used in order to determine phase compositions of the raw $\mathrm{Al}_{2} \mathrm{O}_{3}$ and $\mathrm{ZrO}_{2}$ powder and heat treated $\mathrm{Al}_{2} \mathrm{O}_{3}-\mathrm{ZrO}_{2}$ composites at $1650{ }^{\circ} \mathrm{C}$. The device used was Shimadzu XRD6000 (Shimadzu Corporation, Kyoto, Japan) X-ray diffractometer with $\mathrm{CuK} \alpha$ radiation. The fixed step scans were collected in the $2 \theta$ range $20-60^{\circ}$ with steps of $0.02^{\circ} 2 \theta$ and counting time $0.6 \mathrm{~s}$ under accelerating voltage of $40 \mathrm{kV}$ and current of $30 \mathrm{~mA}$.

\subsection{Suspension Preparation and Characterization}

Four groups of alumina-zirconia aqueous suspensions were prepared. All suspensions contained $70 \mathrm{wt}$. \% of dry ceramic powder and $30 \mathrm{wt}$. \% of deionized water. The dry powder composition was as follows:

- 100 wt. $\% \mathrm{Al}_{2} \mathrm{O}_{3}$

- 99 wt. $\% \mathrm{Al}_{2} \mathrm{O}_{3}$ and 1 wt. \% of $\mathrm{ZrO}_{2}$

- 95 wt. $\% \mathrm{Al}_{2} \mathrm{O}_{3}$ and 5 wt. \% of $\mathrm{ZrO}_{2}$

- 90 wt. $\% \mathrm{Al}_{2} \mathrm{O}_{3}$ and 10 wt. \% of $\mathrm{ZrO}_{2}$.

DOLAPIX CE 64 dispersant was used for the electrosteric stabilization of all ceramic suspensions. The structure of the functional group of the dispersant is shown in Figure 2.

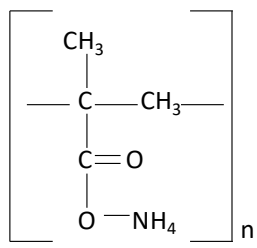

Figure 2. The molecule structure of dispersant Dolapix CE 64.

The optimal amount of the dispersant was determined for each suspension separately. The composition of the different suspensions for determining the optimal amount of DOLAPIX CE 64 are given in Table 3. The optimal amount of dispersant was determined by measuring the apparent viscosity as a function of the amount of dispersant added. In previous research, it was found that addition of magnesium aluminate spinel $\left(\mathrm{MgAl}_{2} \mathrm{O}_{4}\right)$ does not affect the apparent viscosity of the high concentrate alumina suspension [22]. The viscosity is at minimum value when the dispersion of ceramic particles is optimal.

Table 3. The composition of suspensions for determining the optimal amount of dispersant DOLAPIX CE 64 .

\begin{tabular}{|c|c|c|c|c|}
\hline Sample & $\begin{array}{l}\text { wt. (Ceramic } \\
\text { Powder), \% }\end{array}$ & Ceramic Powder Composition & wt. $\left(\mathrm{MgAl}_{2} \mathrm{O}_{4}\right) * \%$ & $\begin{array}{c}\text { wt. (Dolapix CE } \\
64) *, \%\end{array}$ \\
\hline 1 & 70 & 100 wt. $\% \mathrm{Al}_{2} \mathrm{O}_{3}$ & 0.2 & 0.15 to 1.0 \\
\hline 2 & 70 & 99 wt. $\% \mathrm{Al}_{2} \mathrm{O}_{3}+1$ wt. $\% \mathrm{ZrO}_{2}$ & 0.2 & 0.2 to 1.0 \\
\hline 3 & 70 & 95 wt. $\% \mathrm{Al}_{2} \mathrm{O}_{3}+5$ wt. $\% \mathrm{ZrO}_{2}$ & 0.2 & 0.4 to 1.2 \\
\hline 4 & 70 & 90 wt. $\% \mathrm{Al}_{2} \mathrm{O}_{3}+10$ wt. $\% \mathrm{ZrO}_{2}$ & 0.2 & 0.8 to 1.4 \\
\hline
\end{tabular}

* weight percentage based on the amount of dry ceramic powder.

For determining the apparent viscosity all suspensions were prepared by adding deionized water containing dissolved DOLAPIX CE 64 into the grinding jar of a planetary ball mill, after which ceramic 
powders were added. The grinding jar and ten balls used for homogenization were made of alumina ceramics in order to prevent the contamination of suspensions. Each of the prepared suspensions were homogenized for $90 \mathrm{~min}$ at a rate of $300 \mathrm{rpm}$ in the planetary ball mill (PM 100, Retsch, Haan, Germany). After mixing, the ceramic balls were separated from the suspensions. Prior to the apparent viscosity measurement and forming of the green bodies, suspensions were ultrasonically treated in the ultrasonic bath BRANSONIC 220 (Branson Ultrasonics Corp., Danbury, CT, USA) with $50 \mathrm{kHz}$ frequency and power of $120 \mathrm{~W}$ to remove trapped air bubbles and agglomerates, as well as tempered at $25 \pm 1{ }^{\circ} \mathrm{C}$ with the assistance of the thermostatic bath Lauda Eco RE 415 (LAUDA-Brinkmann, Delran, NJ, USA).

The apparent viscosity of each suspension was determined by means of the rotational viscometer DV-III Ultra (Brookfield Engineering Laboratories, Middleboro, MA, USA) with small sample chamber and SC4-18 spindle. Viscosity was determined at the shear rate of $50 \mathrm{~s}^{-1}$, which is the exact shear rate of gravity slip casting.

After completing the rheological measurements and finding the optimum amount of the dispersant, sedimentation tests were performed. Four groups of suspensions were additionally prepared with the optimum amount of dispersant. The $\mathrm{pH}$-values of these prepared suspensions were determined on the FE20/EL20 pH meter (error range 0.01) manufactured by Mettler Toledo GmbH (Greifensee, Switzerland). In this case the $\mathrm{pH}$ value of the samples did not change, it was done only for the confirmation of the stability of the optimized suspensions.

\subsection{Sintering of Monolithic Alumina and Composite Alumina-Zirconia Ceramics}

Monolithic $\mathrm{Al}_{2} \mathrm{O}_{3}$ and composite $\mathrm{Al}_{2} \mathrm{O}_{3}-\mathrm{ZrO}_{2}$ ceramics were prepared by conventional sintering of green bodies formed by slip casting forming method. Therefore, after the apparent viscosity measurement the suspensions were poured into previously prepared gypsum molds and air-dried. The gypsum mold draws water from the poured slip and gives a form to the green body.

Afterwards, dried samples were removed from molds. The green bodies were sintered in the high-temperature furnace P 310 (Nabertherm, Lilienthal, Germany) by the following regime: initial heating at a rate of $3{ }^{\circ} \mathrm{C} / \mathrm{min}$ up to the temperature of $500{ }^{\circ} \mathrm{C}$, holding at $500{ }^{\circ} \mathrm{C}$ for $1 \mathrm{~h}$, followed by heating at a rate of $5{ }^{\circ} \mathrm{C} / \mathrm{min}$ up to the temperature of $1650^{\circ} \mathrm{C}$, holding at $1650{ }^{\circ} \mathrm{C}$ for $2 \mathrm{~h}$ and finally slow cooling in the furnace to room temperature (Figure 3). After sintering, the Archimedes density was measured for all samples.

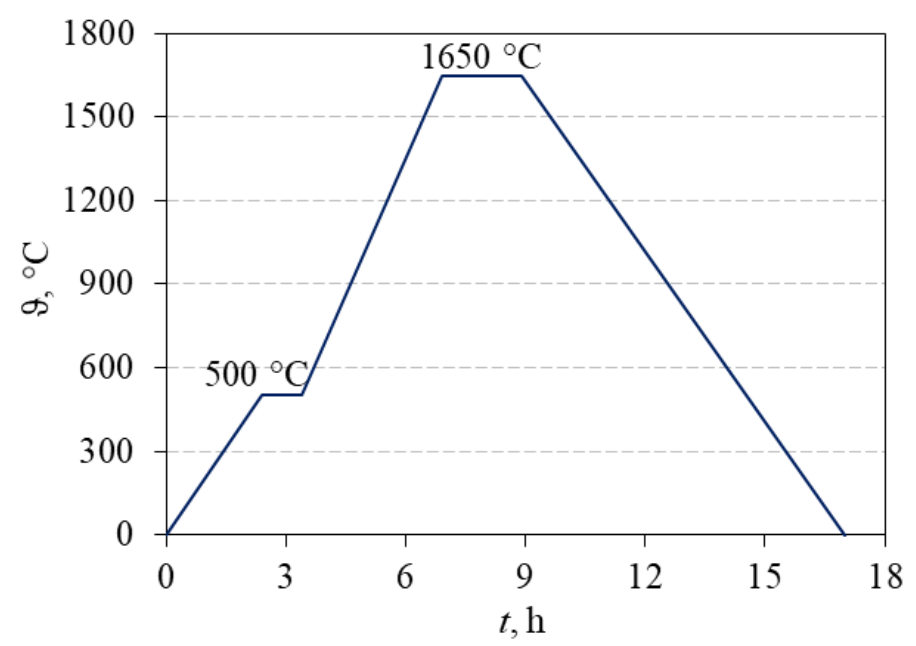

Figure 3. Schema of sintering regime of monolithic $\mathrm{Al}_{2} \mathrm{O}_{3}$ and $\mathrm{Al}_{2} \mathrm{O}_{3}-\mathrm{ZrO}_{2}$ composite ceramics. 


\subsection{Characterisation of Monolithic Alumina and Composite Alumina-Zirconia Ceramics}

Sintered samples were prepared for the following tests according to the standard ceramographic technique [28]. Surface morphology of the sintered ceramic samples was determined by the scanning electron microscope (SEM), Tescan Vega Easy Probe 3, Brno-Kohoutovice, Czech Republic operating at $10 \mathrm{kV}$, additionally equipped with energy dispersive spectrometer (EDS), Oxford Instruments, Abingdon, UK. Distribution of the elements aluminum (Al), zirconium $(\mathrm{Zr})$ oxygen $(\mathrm{O})$ and yttrium $(\mathrm{Y})$ on fracture surface of sintered samples was determined by EDS mapping.

Vickers hardness (HV30) of sintered ceramic samples was measured under $294 \mathrm{~N}$ indentation load by means of hardness tester 5030 TKV (Indentec Hardness Testing Machines Ltd., West Midlands, UK). The "Vickers indentation fracture, (VIF)" or "Vickers indentation crack length" method was used for fracture toughness determination of all ceramic samples. This method uses a Vickers indenter to make a hardness indentation on a polished ceramic sample surface. The indenter creates a plastically-deformed region underneath the indenter as well as cracks that emanate radially outward and downward from the vertices of the Vickers indentation. Besides radial-median cracks, Palmqvist cracks can also occur (Figure 4). A simple way to differentiate between the two types is to polish the surface layers away: the median crack system will always remain connected to the inverted pyramid of the indentation, while the Palmqvist cracks will become detached, as shown in Figure 4.
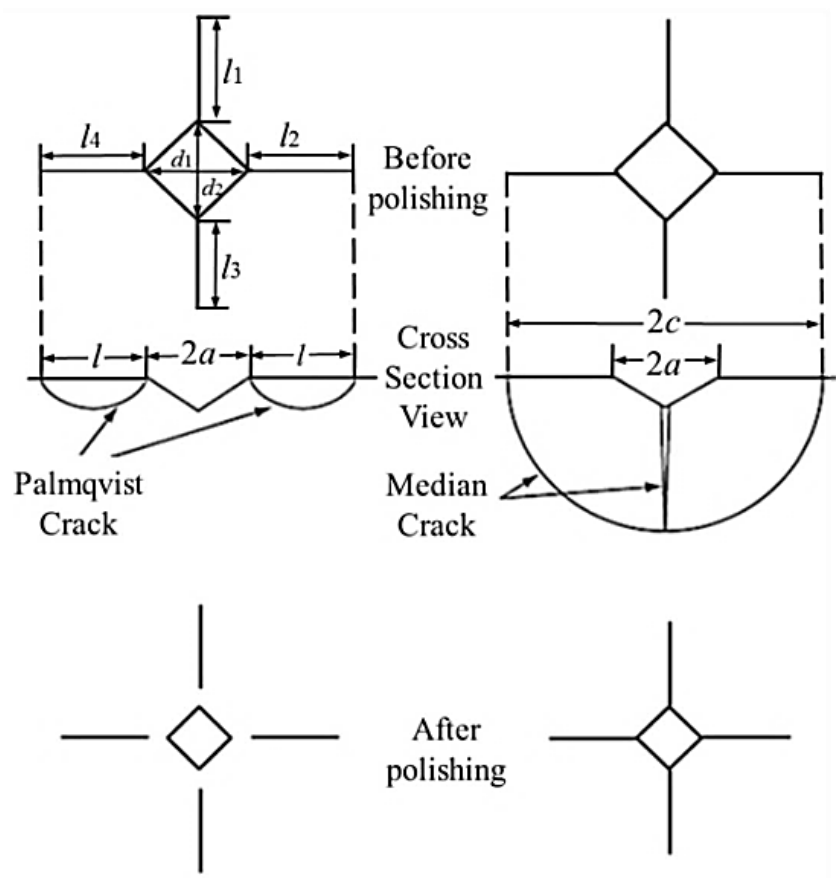

Figure 4. Palmqvist and median crack system developed from the Vickers indents, before and after polishing [29].

In the order to calculate Vickers indentation fracture toughness, the lengths of these cracks were measured. Fracture toughness is calculated on the basis of the crack lengths, the indentation load, the hardness, the elastic modulus, the indentation diagonal size, and an empirical fitting constant. Nine equations based on the Palmqvist, radial-median cracks and both were found to be applicable for the fracture toughness determination of the ceramics (Table 4$)$. The brittleness index $\left(B_{\mathrm{i}}, \mu \mathrm{m}^{-1 / 2}\right) \mathrm{was}$ calculated from the ratio of Vickers hardness and Vickers indentation fracture toughness. 
Table 4. Models by different authors for calculation of Vickers indentation fracture toughness $\left(K_{\mathrm{IC}}\right)$ values for different crack types [29].

\begin{tabular}{ccc}
\hline Crack Type & Model & Author(s) of Model \\
\hline Palmqvist & $K_{\mathrm{IC}}=0.024 \times \frac{F}{c^{1.5}} \times\left(\frac{E}{H V}\right)^{0.5}$ & Casellas [2,30] \\
\hline Palmqvist & $K_{\mathrm{IC}}=0.0028 \times H V^{0.5}\left(\frac{F}{T}\right)^{0.5}$ & Palmqvist [31] \\
\hline Palmqvist & $K_{\mathrm{IC}}=0.0319 \times \frac{F}{a \cdot l^{0.5}}$ & Shetty et al. [32] \\
\hline Palmqvist & $K_{\mathrm{IC}}=0.0089 \times\left(\frac{E}{H V}\right)^{0.4} \times \frac{F}{a \cdot l^{0.5}}$ & Niihara et al. [32] \\
\hline for $0.25<l / a<2.5$ & Anstis [1,2,33] \\
\hline Median & $K_{\mathrm{IC}}=0.016 \times \frac{F}{c^{1.5}} \times\left(\frac{E}{H V}\right)^{0.5}$ & Evans and Charles [34] \\
\hline Median & $K_{\mathrm{IC}}=0.0752 \times \frac{F}{c^{1.5}}$ & Tanaka [34] \\
\hline Median & $K_{\mathrm{IC}}=0.0725 \times \frac{F}{c^{1.5}}$ & Niihara, Morena and Hasselman \\
(NMH) [35]
\end{tabular}

$F$, applied load during Vickers test $(\mathrm{N}) ; c$, the crack length from the center of the indentation to the crack tip (m); $E$, Young's modulus (GPa); $H V$, the Vickers hardness $(\mathrm{GPa}) ; l$, the crack length measured from vertices of the indentation to the crack tip (m); $T$, the total crack length $(\mathrm{m}): T=l_{1}+l_{2}+l_{3}+l_{4} ; a$, half of the indentation diagonal (m).

\section{Results and Discussion}

From the diffractogram in Figure 5, the qualitative crystalline composition determination was possible for all samples. The diffractogram in Figure 5 indicates that the raw $\mathrm{Al}_{2} \mathrm{O}_{3}$ consists of only $\alpha-\mathrm{Al}_{2} \mathrm{O}_{3}$ crystalline phase (corundum) (ICDD PDF\#46-1212). On the other hand, for raw $\mathrm{ZrO}_{2}$ powder two phases were assigned to the main phase; zirconia tetragonal phase $\left(t-\mathrm{ZrO}_{2}\right)(\mathrm{ICDD}$ PDF\#42-1164) and the minor phase; zirconia monoclinic phase $\left(m-\mathrm{ZrO}_{2}\right)(\mathrm{ICDD}$ PDF\#37-1484). Amorphous phase or residuals are not present. Qualitatively, sintered zirconia-toughened alumina composite shows the presence of $\alpha-\mathrm{Al}_{2} \mathrm{O}_{3}$ (ICDD PDF\#46-1212) as the main phase, $t-\mathrm{ZrO}_{2}$ (ICDD PDF\#42-1164) as the minor phase and $m-\mathrm{ZrO}_{2}$ (ICDD PDF\#37-1484) in traces. With increase of the zirconia content, both $t-\mathrm{ZrO}{ }_{2}$ and $m-\mathrm{ZrO}_{2}$ intensity increased (the intensity increase of the $t-\mathrm{ZrO}_{2}$ phase peak is shown in Inset). Semiquantitatively, the loading of the $t-\mathrm{ZrO}_{2}$ is also shown in Inset (having in mind $\mathrm{Al}_{2} \mathrm{O}_{3}$ and $\mathrm{ZrO}_{2}$ show different absorption coefficients, the loading should only point out to a trend between different values and not to exact values).

The intensity of the $t-\mathrm{ZrO}_{2}$ strongest peak and $m-\mathrm{ZrO}_{2}$ strongest peak were compared to allow an insight in the mutual dependence of the zirconia phases $\left(t-\mathrm{ZrO}_{2}\right.$ to $m-\mathrm{ZrO}_{2}$ ratio) as a function of the zirconia loading. With the introduction of $1 \mathrm{wt}$. \% of zirconia, the relative content of the $m-\mathrm{ZrO}_{2}$ is about $15 \mathrm{wt}$. \% ( $85 \mathrm{wt}$. \% $t-\mathrm{ZrO}_{2}$ ). However, the calculation of the ratio of phases that are present in levels of about $1 \%$ is questionable. Upon an increase in the zirconia loading to $5 \mathrm{wt}$. \%, the relative presence of the $m-\mathrm{ZrO}_{2}$ is reduced to about $7 \%\left(93 \% t-\mathrm{ZrO}_{2}\right)$, and the similar ratio remains for further increase of the zirconia loading up to $10 \mathrm{wt}$. \%. Basically, the ratio between $m-\mathrm{ZrO}_{2}$ and $t-\mathrm{ZrO}_{2}$ zirconia phases remains the same. This actually makes sense as there is no clear reason why the increased zirconia content would affect the ratio between $m-\mathrm{ZrO}_{2}$ and $t-\mathrm{ZrO}_{2}$ zirconia. The only reason could be the consequence of the phase transformation from tetragonal into monoclinic phase in the cracking zone (closure of the crack due to the volume changes). However, such microeffects are not statistically observable using a method like XRD. The important issue is that for the healing of the crack there is plenty of the main zirconia phase, the $t-\mathrm{ZrO}_{2}$ available [36,37]. As the microstructure is considered, the use of raw $\alpha$-alumina yields crystallites of about $262 \mathrm{~nm}$ in size, while raw zirconia yields crystallites of about $32 \mathrm{~nm}$. Crystallite size was calculated by applying the Scherrer equation on the XRD patterns. 
Some growth occurs in the subsequent process, as ceramic with pure alumina yields $324 \mathrm{~nm}$, where 1 and $5 \mathrm{wt}$. \% of zirconia in composites marginally affect the crystallite size (370 and $369 \mathrm{~nm}) .10 \mathrm{wt}$. \% of zirconia definitively impacts the microstructure of composites, reducing the crystallite size to $314 \mathrm{~nm}$.

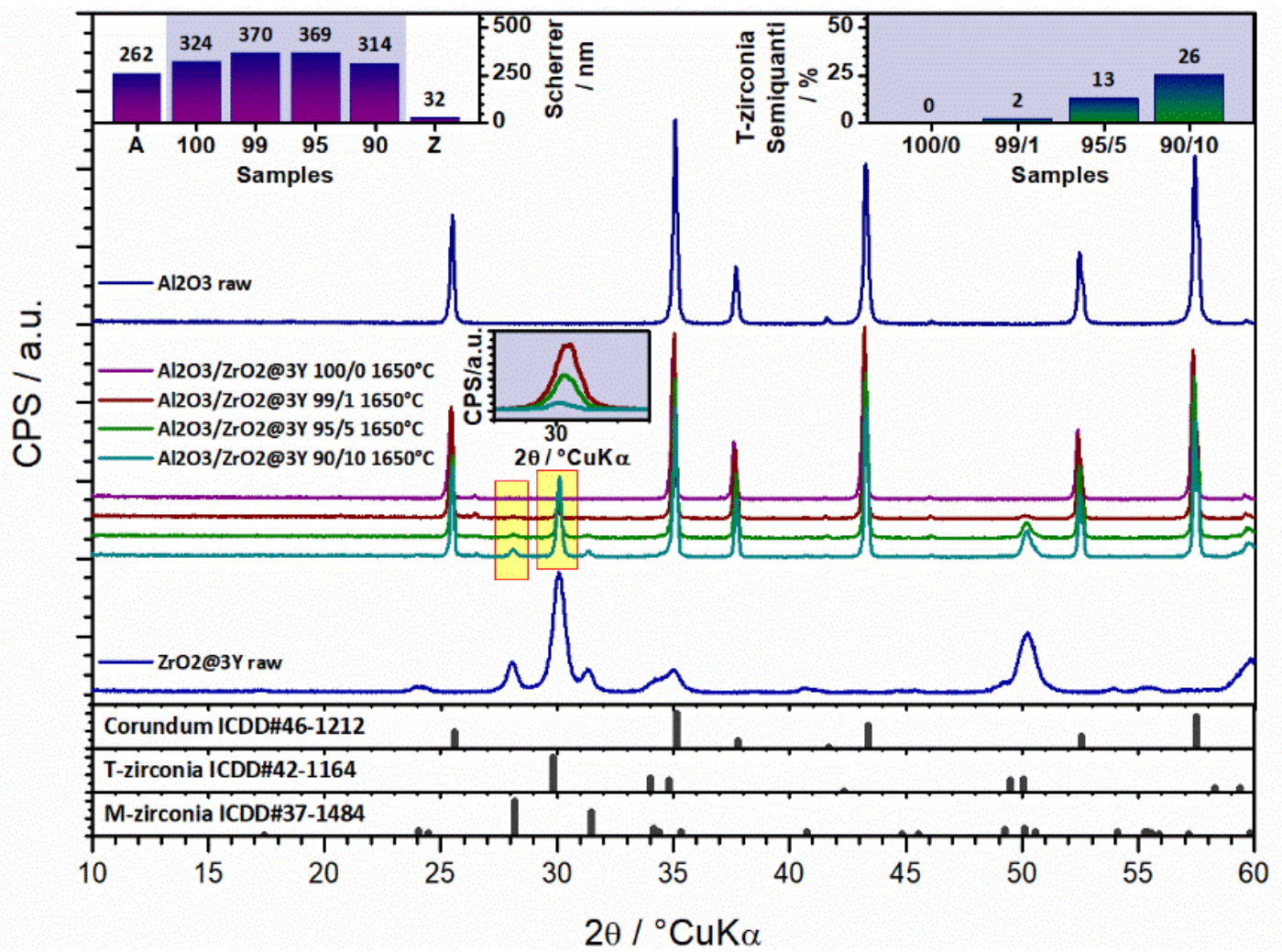

Figure 5. XRD patterns of raw $\mathrm{Al}_{2} \mathrm{O}_{3}, \mathrm{ZrO}_{2}$ and thermal treated $\left(1650^{\circ} \mathrm{C}\right) \mathrm{Al}_{2} \mathrm{O}_{3}-\mathrm{ZrO}_{2}$ composite powders.

Viscosity measurements were used for the suspension stability estimation. Rheological measurements showed that measured apparent viscosity increases with the increasing zirconia content. The optimal amount of Dolapix CE 64 also increases with the increasing zirconia content. The diagram in Figure 6 shows the apparent viscosity at the shear rate of app. $50 \mathrm{~s}^{-1}$, which is the shear rate of the gravity slip casting.

The obtained minimum viscosity values represent the most stable suspension, which served as the guideline for the preparation of the most suitable ceramic suspensions to be poured into the mold to prepare green bodies and to be sintered, in order to get the samples of monolithic $\mathrm{Al}_{2} \mathrm{O}_{3}$ and $\mathrm{Al}_{2} \mathrm{O}_{3}-\mathrm{ZrO}_{2}$ composite ceramics.

By comparing the results in Figure 6 it is evident that the optimum amount of the dispersant increases with increased $\mathrm{ZrO}_{2}$ content. The reason for this is probably the fact that this component has finer particles. Ceramic particles of smaller dimensions have a larger specific surface. Therefore, the area that the macromolecules of the dispersant must cover to ensure the stability of the system is larger. Hence, a higher amount of the dispersant is needed to stabilize such suspensions [18]. 


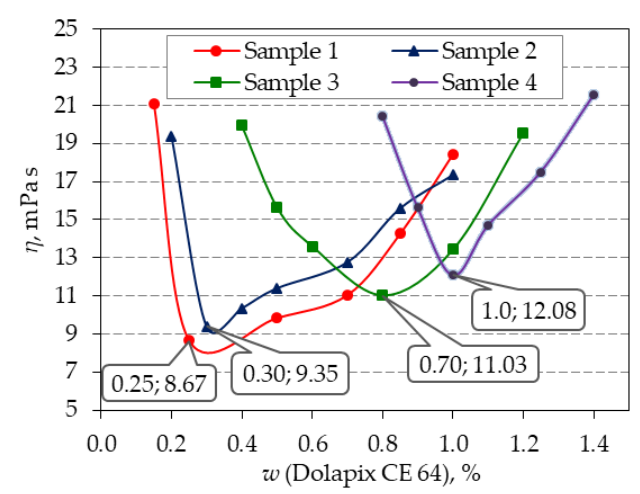

Figure 6. Influence of amounts of Dolapix CE 64 dispersant (wt. \%) on apparent viscosity $(\eta)$ of the 70 wt. \% suspensions with ceramic powder composition of sample 1: $100 \mathrm{wt}$. $\% \mathrm{Al}_{2} \mathrm{O}_{3}$; sample 2: 99 wt. $\% \mathrm{Al}_{2} \mathrm{O}_{3}+1$ wt. $\% \mathrm{ZrO}_{2}$; sample 3: 95 wt. $\% \mathrm{Al}_{2} \mathrm{O}_{3}+5$ wt. $\% \mathrm{ZrO}_{2}$; sample $4: 90$ wt. \% $\mathrm{Al}_{2} \mathrm{O}_{3}+$ 10 wt. $\% \mathrm{ZrO}_{2}$.

Table 3 shows the composition of the tested suspensions, while the optimal compositions (i.e., optimal dispersant amount) are shown in Table 5.

Table 5. The compositions of stable suspensions for preparation of monolithic $\mathrm{Al}_{2} \mathrm{O}_{3}$ and $\mathrm{Al}_{2} \mathrm{O}_{3}-\mathrm{ZrO}_{2}$ composite ceramics.

\begin{tabular}{ccccc}
\hline Sample & $\begin{array}{c}\text { wt. (Ceramic } \\
\text { Powder), } \%\end{array}$ & Ceramic Powder Composition & wt. $\left(\mathbf{M g A l}_{\mathbf{2}} \mathbf{O}_{4}\right) *, \%$ & $\begin{array}{c}\text { Optimal Amount } \\
\text { of Dispersant }\end{array}$ \\
\hline 1 & 70 & 100 wt. $\% \mathrm{Al}_{2} \mathrm{O}_{3}$ & 0.2 & 0.25 wt. $\%$ \\
2 & 70 & 99 wt. $\% \mathrm{Al}_{2} \mathrm{O}_{3}+1$ wt. $\% \mathrm{ZrO}_{2}$ & 0.2 & 0.30 wt. \% \\
3 & 70 & 95 wt. $\% \mathrm{Al}_{2} \mathrm{O}_{3}+5$ wt. $\% \mathrm{ZrO}_{2}$ & 0.2 & 0.70 wt. $\%$ \\
4 & 70 & 90 wt. $\% \mathrm{Al}_{2} \mathrm{O}_{3}+10$ wt. $\% \mathrm{ZrO}_{2}$ & 0.2 & 1.00 wt. \% \\
\hline
\end{tabular}

${ }^{*}$ wt., weight percent based on the applied ceramic dry powder.

In this study no typical sedimentation tests were performed [14,38], meaning, the sedimentation rate of the suspension was not observed depending on the $\mathrm{pH}$ value. Only the sedimentation rates for suspensions with the optimum proportion of the dispersant at their "natural" pH value were measured. The measured $\mathrm{pH}$ values of the real samples and their mean values of three measurements are shown in Table 6.

Table 6. Measurement results of $\mathrm{pH}$ values on real samples of stable suspensions of monolithic $\mathrm{Al}_{2} \mathrm{O}_{3}$ and $\mathrm{Al}_{2} \mathrm{O}_{3}-\mathrm{ZrO}_{2}$ composite ceramics ( $\bar{x}$-mean, s-experimental standard deviation).

\begin{tabular}{|c|c|c|c|c|}
\hline \multirow{2}{*}{ pH Value } & \multicolumn{4}{|c|}{ Sample } \\
\hline & 100 wt. $\% \mathrm{Al}_{2} \mathrm{O}_{3}$ & $\begin{array}{c}99 \text { wt. } \% \mathrm{Al}_{2} \mathrm{O}_{3}+ \\
1 \text { wt. } \% \mathrm{ZrO}_{2}\end{array}$ & $\begin{array}{c}95 \text { wt. } \% \mathrm{Al}_{2} \mathrm{O}_{3}+ \\
5 \text { wt. } \% \mathrm{ZrO}_{2}\end{array}$ & $\begin{array}{c}90 \text { wt. } \% \mathrm{Al}_{2} \mathrm{O}_{3}+ \\
10 \text { wt. } \% \mathrm{ZrO}_{2}\end{array}$ \\
\hline $\bar{x} \pm s$ & $8.92 \pm 0.06$ & $8.36 \pm 0.05$ & $8.52 \pm 0.09$ & $8.26 \pm 0.10$ \\
\hline
\end{tabular}

The prepared suspensions did not show any indication of phase separation after 3 days and the suspensions were still homogeneous. Full separation of the solid and liquid phase was observed after more than seven days in all four suspension groups. For this reason, the prepared suspensions can be considered stable [14,38], without the need for $\mathrm{pH}$ control.

The results of SEM-EDS analysis of surface fracture of sintered monolithic $\mathrm{Al}_{2} \mathrm{O}_{3}$ and $\mathrm{Al}_{2} \mathrm{O}_{3}-\mathrm{ZrO}_{2}$ composite ceramics are shown in Figures 7-11. It can be seen (Figure 7b-d, Figures 9-11) that the $\mathrm{ZrO}_{2}$ particles (the brighter phase) are distributed in $\mathrm{Al}_{2} \mathrm{O}_{3}$ matrix, with some agglomerates of $\mathrm{ZrO}_{2}$ and some pores. These observations were additionally confirmed by the SEM-EDS mapping of the surface fracture of sintered samples (Figures 9-11). 
The composites with 5 and 10 wt. \% $\mathrm{ZrO}_{2}$ have shown larger agglomerates of $\mathrm{ZrO}_{2}$ in $\mathrm{Al}_{2} \mathrm{O}_{3}$ matrix compared to $1 \mathrm{wt}$. $\% \mathrm{ZrO}_{2}$ (Figure $7 \mathrm{~b}-\mathrm{d}$ )). The pores are mostly distributed around $\mathrm{ZrO}_{2}$ agglomerates. Also, the increasing of $\mathrm{ZrO}_{2}$ content has resulted in a reduction of $\mathrm{Al}_{2} \mathrm{O}_{3}$ grain size. All these microstructural characteristics typically affect the mechanical properties, such as hardness and fracture toughness.
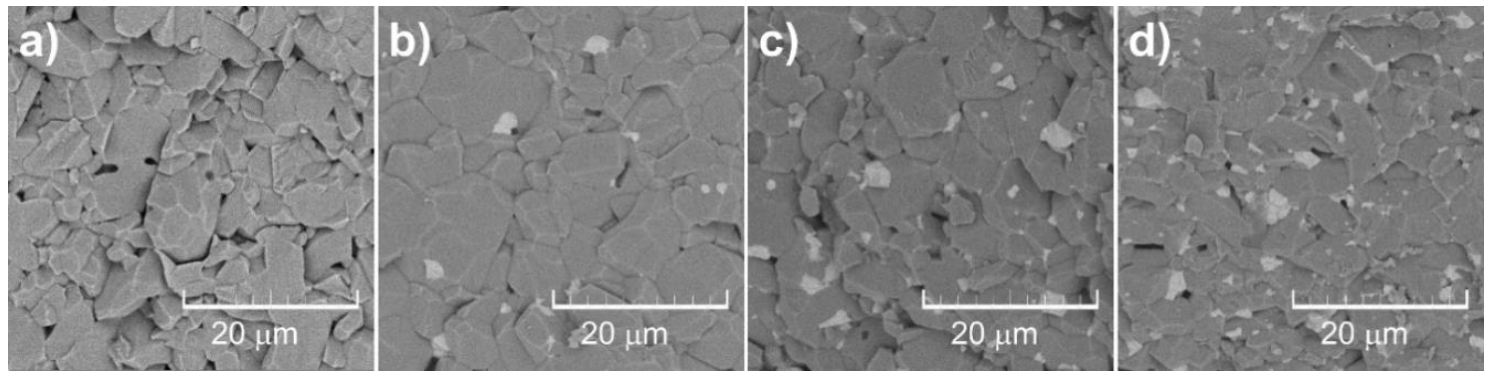

Figure 7. Surface fracture of $\mathrm{Al}_{2} \mathrm{O}_{3}-\mathrm{ZrO}_{2}$ composite ceramics with different content of $\mathrm{ZrO}_{2}$ : (a) 0 wt. \%; (b) 1 wt. \%; (c) 5 wt. \%; (d) 10 wt. \% prepared by slip casting and sintering at $1650{ }^{\circ} \mathrm{C}$.
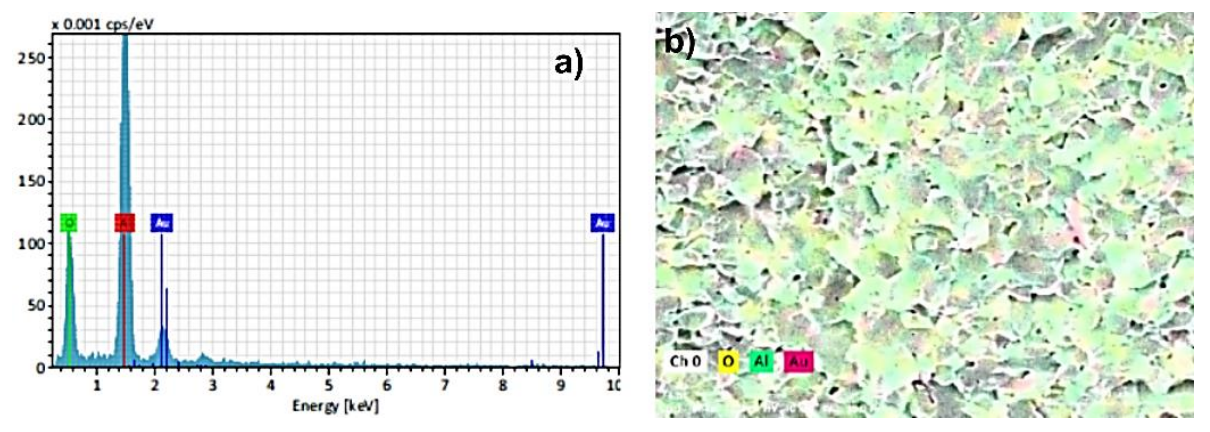

Figure 8. (a) EDS spectra and (b) SEM micrographs of surface fracture of $\mathrm{Al}_{2} \mathrm{O}_{3}$ ceramics.
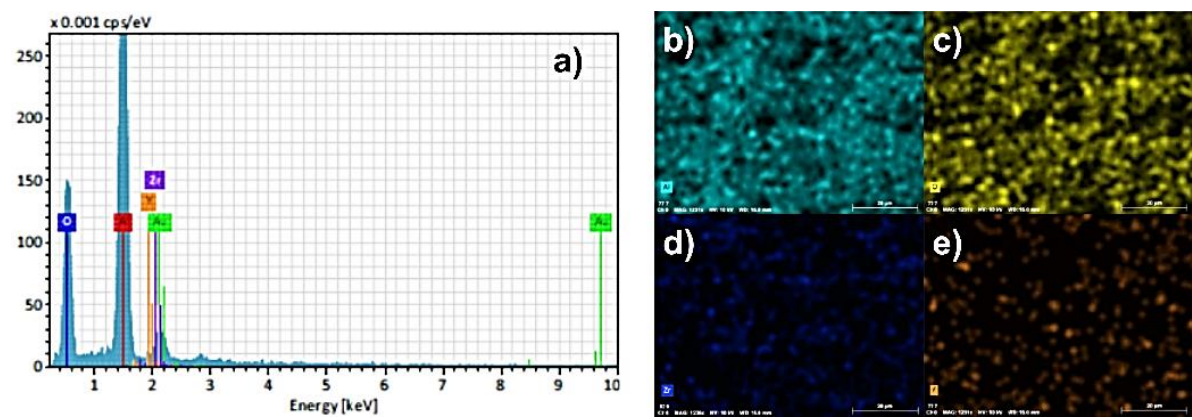

Figure 9. (a) EDS spectra of surface fracture of $\mathrm{Al}_{2} \mathrm{O}_{3}-\mathrm{ZrO}_{2}$ ceramics with 1 wt. $\%$ of $\mathrm{ZrO}_{2}$ and corresponding element mappings: (b) Aluminum (Al); (c) Oxygen $(\mathrm{O})$; (d) Zirconium $(\mathrm{Zr})$; (e) Yttrium (Y). 

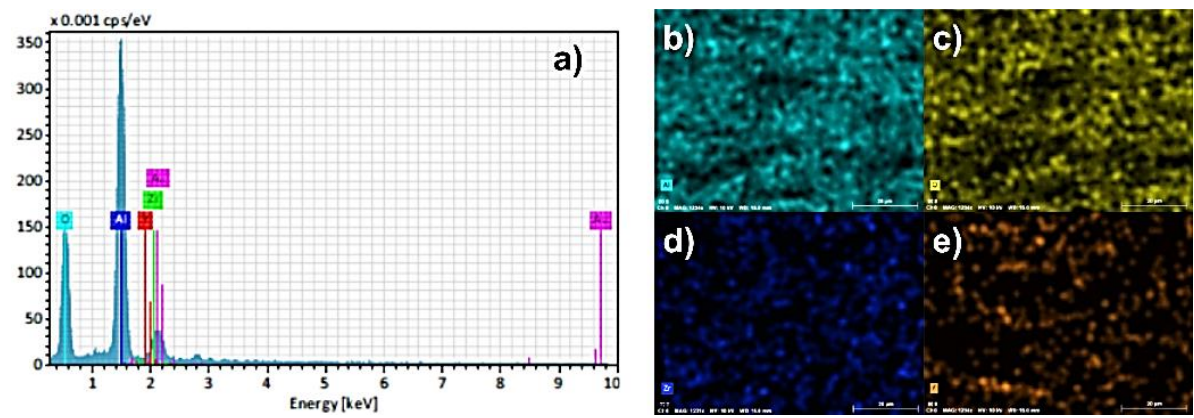

Figure 10. (a) EDS spectra of surface fracture of $\mathrm{Al}_{2} \mathrm{O}_{3}-\mathrm{ZrO}_{2}$ ceramics with 5 wt. $\%$ of $\mathrm{ZrO}_{2}$ and corresponding element mappings: (b) Aluminum (Al); (c) Oxygen $(\mathrm{O})$; (d) Zirconium $(\mathrm{Zr})$; (e) Yttrium (Y).
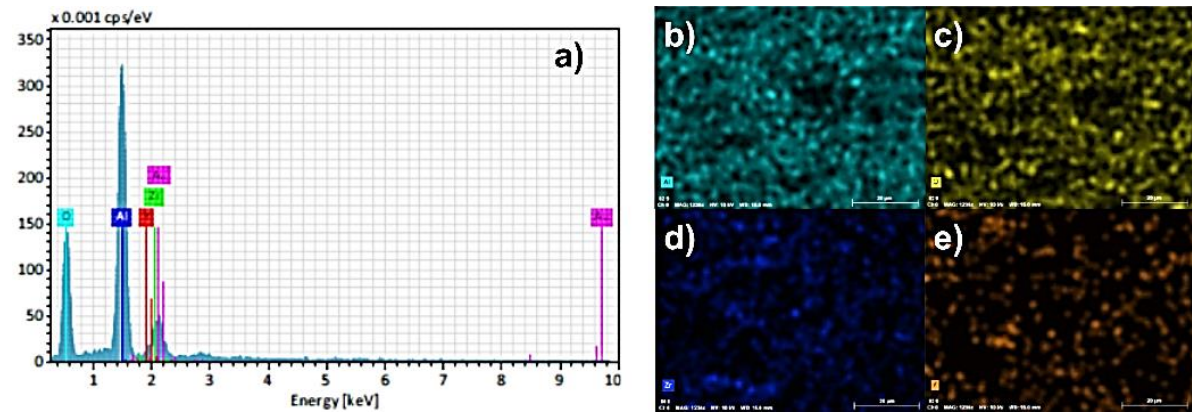

Figure 11. (a) EDS spectra of surface fracture of $\mathrm{Al}_{2} \mathrm{O}_{3}-\mathrm{ZrO}_{2}$ ceramics with 10 wt. $\%$ of $\mathrm{ZrO}_{2}$ and corresponding element mappings: (b) Aluminum (Al); (c) Oxygen (O); (d) Zirconium (Zr); (e) Yttrium (Y).

The results of measuring the density of sintered samples $\left(\mathrm{Al}_{2} \mathrm{O}_{3}\right.$ and $\mathrm{Al}_{2} \mathrm{O}_{3}-\mathrm{ZrO}_{2}$ composite) confirm that the density increases with increasing the $\mathrm{ZrO}_{2}$ content (Table 7). The theoretical density of pure $\mathrm{Al}_{2} \mathrm{O}_{3}$ is $3.97 \mathrm{~g} / \mathrm{cm}^{3}$ and of pure $\mathrm{ZrO}_{2} 6.10 \mathrm{~g} / \mathrm{cm}^{3}$. From these theoretical densities of pure ceramics, weight content of components, and from the measured bulk densities, the relative densities of each sample were calculated (Table 7). The highest relative densities were recorded for pure $\mathrm{Al}_{2} \mathrm{O}_{3}$ and for the composite with $1 \mathrm{wt}$. $\% \mathrm{ZrO}_{2}$. When $\mathrm{ZrO}_{2}$ content was increased to 5 and $10 \mathrm{wt}$. \%, the relative density decreased and consequently the porosity has increased. Similar results were published previously [39].

The Vickers indentation method was used for the determination of hardness ( $H V 30)$, fracture toughness $\left(K_{\mathrm{IC}}\right)$ and brittleness index $\left(B_{\mathrm{i}}\right)$ of sintered samples of monolithic $\mathrm{Al}_{2} \mathrm{O}_{3}$ and $\mathrm{Al}_{2} \mathrm{O}_{3}-\mathrm{ZrO}_{2}$ composite ceramics. The results (Table 7) showed that the hardness of the prepared samples decreased with the increased $\mathrm{ZrO}_{2}$ content. There are several reasons for this phenomenon. One of them is the fact that zirconia has lower hardness than $\mathrm{Al}_{2} \mathrm{O}_{3}$. Also, as previously described, the microstructure analysis of composites has shown the coarsening of $\mathrm{ZrO}_{2}$ grains and consequently the formation of porosity. These findings are in correlation with other publications [2,40,41]. Higher relative density, hence higher hardness, may be achieved when, for example, hot-pressing (HP) is used to prepare $\mathrm{Al}_{2} \mathrm{O}_{3}-\mathrm{ZrO}_{2}$ composites [42], hot isostatic pressing [43] or by spark plasma sintering (SPS) [44].

The fracture toughness of the tested samples (Table 8) also increases with the increase of the $\mathrm{ZrO}_{2}$ amount for all applied mathematical models. These results may be assigned to possible phase transformations, formation of microcracks or crack branching [2]. Composite ceramics with $\mathrm{ZrO}_{2}$ grains, exhibit the martensitic phase transformation: when the stress is applied, tetragonal $\mathrm{ZrO}_{2}$ grains transform into monoclinic $\mathrm{ZrO}_{2}$ at the crack tip (Figure 12). 


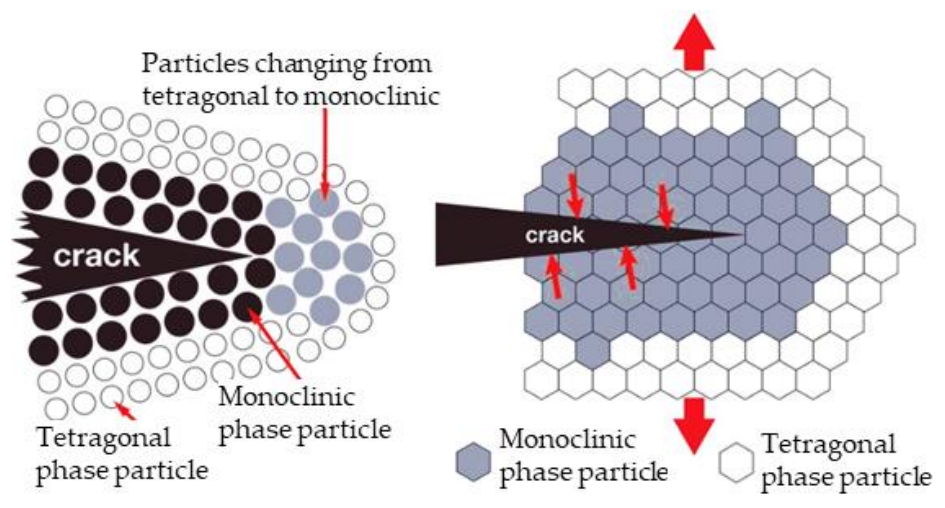

Figure 12. Transformation toughening mechanism in zirconia [29].

This transformation induces a volume expansion from $3-5 \%$, which prevents the crack propagation due to induced compressive stress. This phenomenon is known as the transformation toughening. The larger the $\mathrm{ZrO}_{2}$ content in the composite ceramics, the higher the possibility of crack closure [29]. Besides the zirconia phase transformation, it was found that the alumina grain bridging is also a toughening mechanism which contributes to an increase in toughness of similar alumina zirconia composites [30].

The ratio of the Vickers crack length and half of the Vickers indentation diagonal (c/a, Table 7) indicates the crack type and the crack depth. The crack type is an indirect indicator of material toughness $[1,29,35,45]$. According to the obtained results (Table 7) and interpretation from literature sources $[1,29,35,45]$, median cracks occurred in the first three groups of samples, while shallow, Palmqvist cracks appeared in the fourth group (90 wt. \% $\mathrm{Al}_{2} \mathrm{O}_{3}+10 \mathrm{wt} . \% \mathrm{ZrO}_{2}$ ). It should be emphasized that the c/a ratio for the first three groups of samples is slightly above the limit value of 2.5, so it can be concluded that even low $\mathrm{ZrO}_{2}$ content reduces the crack depth, i.e., increases the toughness. According to Tang et al. [45], samples with a c/a ratio between 2.5 and 3.5 indicate the presence of both types of cracks (both Palmqvist and median), therefore represent the transition between the two types of cracks. According to this interpretation, it is possible to determine the presence of the transitional crack shape (between median and Palmqvist type) in the first three groups of samples, while in the fourth sample group only the Palmqvist cracks occur. According to the obtained c/a values, from 2.3 to 3.9, the most adequate model for the indentation fracture toughness is the Langford model, since it is applicable to both crack types (median and Palmquist).

Table 7. The density, porosity and hardness of $\mathrm{Al}_{2} \mathrm{O}_{3}$ and $\mathrm{Al}_{2} \mathrm{O}_{3}-\mathrm{ZrO}_{2}$ samples and the $c / a$ ratio. Where, $c$ is the crack length from the center of the indentation to the crack tip in $\mathrm{m}$ and $a$ is a half of the indentation diagonal.

\begin{tabular}{|c|c|c|c|c|c|c|}
\hline Sample & Composition & $\begin{array}{l}\text { Bulk Density, } \\
\mathrm{g} / \mathrm{cm}^{3}\end{array}$ & Relative Density, \% & $\begin{array}{c}\text { Total Porosity, } \\
\%\end{array}$ & HV30 & $c / a$ \\
\hline 1 & 100 wt. $\% \mathrm{Al}_{2} \mathrm{O}_{3}$ & 3.882 & 98.04 & 1.96 & 1679 & 3.89 \\
\hline 2 & $\begin{array}{c}99 \text { wt. } \% \mathrm{Al}_{2} \mathrm{O}_{3}+ \\
1 \text { wt. } \% \mathrm{ZrO}_{2}\end{array}$ & 3.920 & 98.21 & 1.79 & 1447 & 2.82 \\
\hline 3 & $\begin{array}{c}95 \text { wt. } \% \mathrm{Al}_{2} \mathrm{O}_{3}+ \\
5 \text { wt. } \% \mathrm{ZrO}_{2}\end{array}$ & 3.931 & 96.43 & 3.57 & 1328 & 2.59 \\
\hline 4 & $\begin{array}{c}90 \text { wt. } \% \mathrm{Al}_{2} \mathrm{O}_{3}+ \\
10 \text { wt. } \% \mathrm{ZrO}_{2}\end{array}$ & 3.938 & 94.14 & 5.86 & 1153 & 2.28 \\
\hline
\end{tabular}

Since not all groups of samples developed the same crack type, not all selected models were applicable to all four sample groups [32]. Nevertheless, all models showed the same trend, i.e., an increase in fracture toughness with increasing $\mathrm{ZrO}_{2}$ content (Table 8 and Figure 13). The obtained results show that the toughness of monolithic $\mathrm{Al}_{2} \mathrm{O}_{3}$ ceramics can be improved by the addition of $\mathrm{ZrO}_{2}$ nanoparticles. 
Table 8. Values of the Vickers indentation fracture toughness for different crack type and models.

\begin{tabular}{|c|c|c|c|c|c|}
\hline \multirow[b]{2}{*}{ Crack Type } & \multirow[b]{2}{*}{ Author(s) of Model } & \multicolumn{4}{|c|}{$K_{\mathrm{IC}}, \mathrm{MPa} \mathrm{m}^{1 / 2}$} \\
\hline & & $\begin{array}{c}\text { Sample } 1 \\
\left(100 \text { wt. } \% \mathrm{Al}_{2} \mathrm{O}_{3}\right)\end{array}$ & $\begin{array}{c}\text { Sample } 2 \\
\text { (99 wt. } \% \mathrm{Al}_{2} \mathrm{O}_{3}+ \\
1 \text { wt. } \% \mathrm{ZrO}_{2} \text { ) }\end{array}$ & $\begin{array}{c}\text { Sample } 3 \\
\text { (95 wt. } \% \mathrm{Al}_{2} \mathrm{O}_{3}+ \\
5 \text { wt. } \% \mathrm{ZrO}_{2} \text { ) }\end{array}$ & $\begin{array}{c}\text { Sample } 4 \\
\left(90 \text { wt. } \% \mathrm{Al}_{2} \mathrm{O}_{3}+\right. \\
10 \text { wt. } \% \mathrm{ZrO}_{2} \text { ) }\end{array}$ \\
\hline Palmqvist & Casellas $[2,30]$ & 5.23 & 8.24 & 9.09 & 10.50 \\
\hline Palmqvist & Palmqvist [31] & 5.94 & 6.87 & 6.90 & 6.92 \\
\hline Palmqvist & Shetty et al. [32] & 6.36 & 7.27 & 7.30 & 7.32 \\
\hline Palmqvist & Niihara et al. [32] & 6.36 & 7.69 & 7.93 & 8.33 \\
\hline Median & Anstis $[1,2,33]$ & 3.48 & 5.49 & 6.06 & 7.00 \\
\hline Median & Evans and Charles [34] & 3.31 & 4.88 & 5.21 & 5.67 \\
\hline Median & Tanaka [34] & 3.20 & 4.70 & 5.02 & 5.47 \\
\hline Median & $\begin{array}{l}\text { Niihara, Morena and } \\
\text { Hasselman (NMH) [35] }\end{array}$ & 4.89 & 7.60 & 8.33 & 9.51 \\
\hline Any kind & Lankford [32] & 5.29 & 8.22 & 9.06 & 10.41 \\
\hline
\end{tabular}

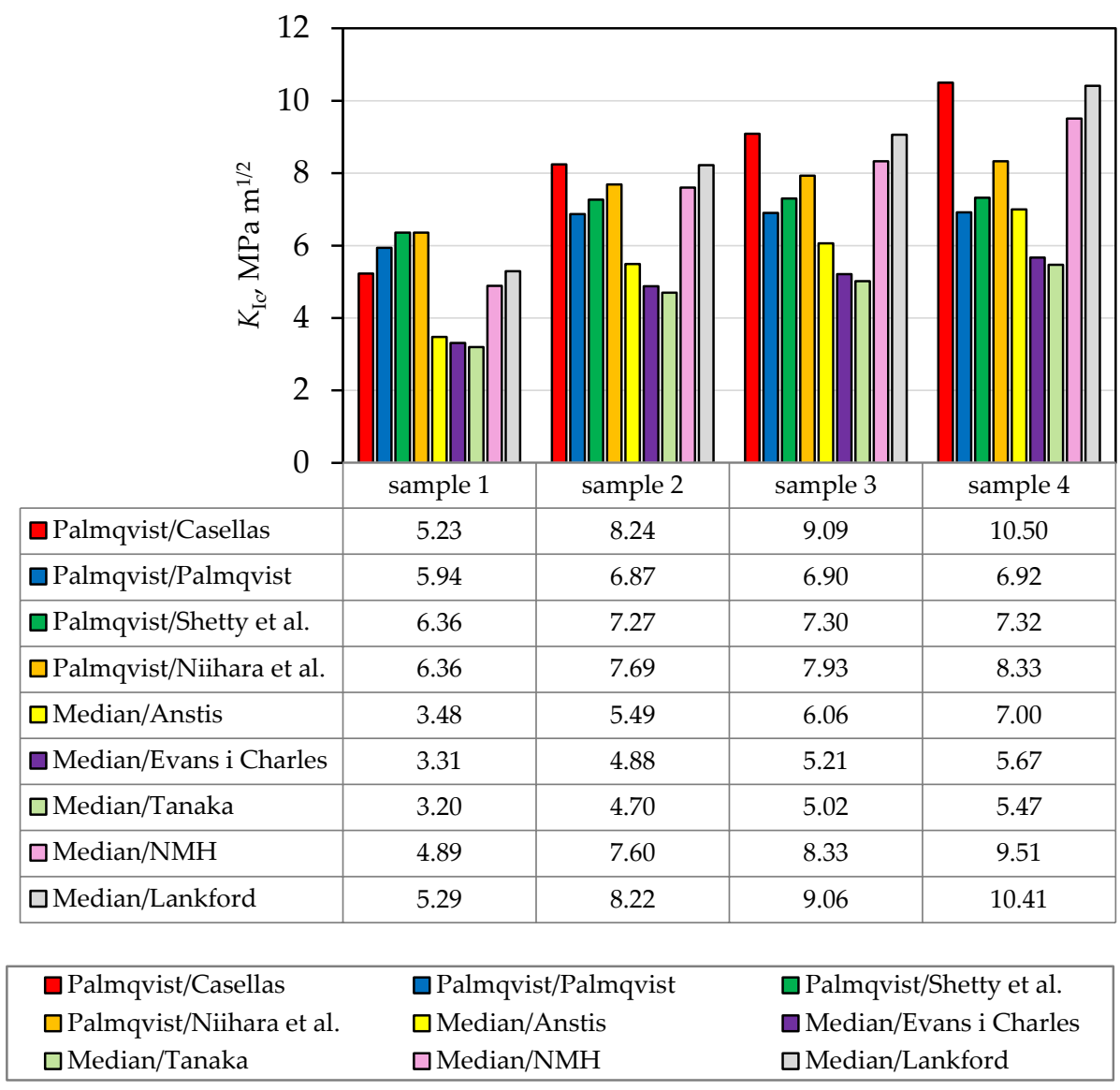

Figure 13. Comparison of Vickers indentation fracture toughness values for different crack types, models and all samples (NMH-Niihara, Morena and Hasselman).

For each sample, the brittleness index $\left(B_{\mathrm{i}}, \mu \mathrm{m}^{-1 / 2}\right)$ was calculated from the ratio of values of Vickers hardness (HV30, GPa) and the Vickers indentation fracture toughness $\left(K_{\mathrm{IC}}, \mathrm{MPa} \mathrm{m}^{1 / 2}\right)$ using Equation (1) [46]:

$$
B_{\mathrm{i}}=\frac{H V}{K_{\mathrm{IC}}}
$$

Calculated values of the brittleness index for all sintered samples are shown in Figure 14. All models showed that the brittleness index decreases with increasing $\mathrm{ZrO}_{2}$ content. 


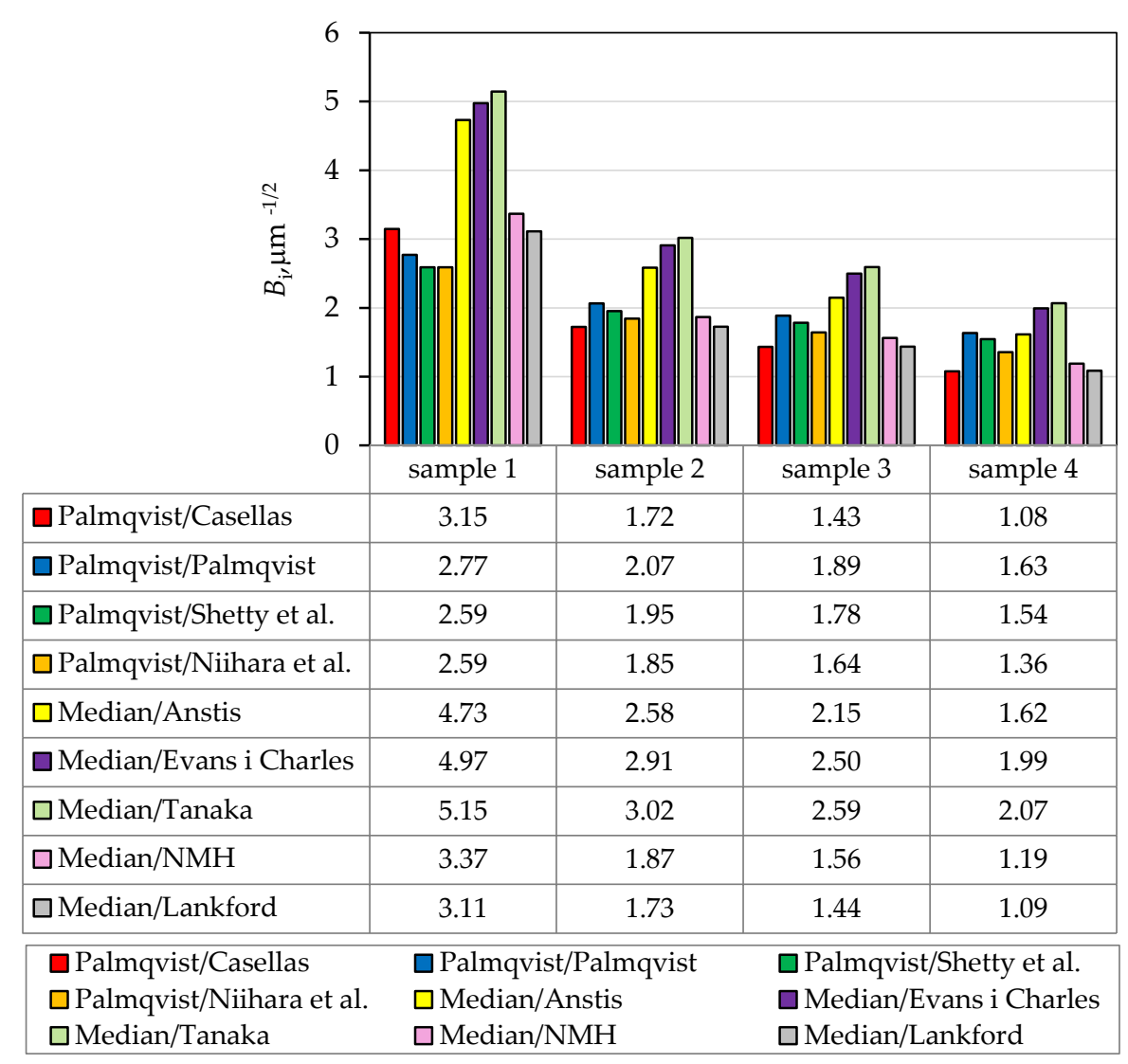

Figure 14. Comparison of brittleness index $\left(B_{\mathrm{i}}, \mu \mathrm{m}^{-1 / 2}\right)$ values for different crack types, models and all samples (NMH-Niihara, Morena and Hasselman).

\section{Conclusions}

In this paper, monolithic $\mathrm{Al}_{2} \mathrm{O}_{3}$ and composite $\mathrm{Al}_{2} \mathrm{O}_{3}-\mathrm{ZrO}_{2}$ ceramics samples were formed by slip casting stable suspensions in gypsum molds. The following conclusions can be drawn as a result of the research:

- XRD analysis confirmed that alumina powder consists of $\alpha$-phase alumina (corundum). The XRD results confirm the changing levels of alumina and zirconia in the composites, and point out to the stable ratio between main tetragonal phase and monoclinic zirconia phase in traces. In addition, the change of the crystallite sizes because of the zirconia loading was quantified.

- With the addition of the commercial dispersant DOLAPIX CE 64, it is possible to prepare stable 70 wt. \% aqueous suspensions of monolithic $\mathrm{Al}_{2} \mathrm{O}_{3}$ and composite $\mathrm{Al}_{2} \mathrm{O}_{3}-\mathrm{ZrO}_{2}$ ceramics using commercial powders.

- $0.25 \mathrm{wt}$ \% of DOLAPIX CE 64 dispersant is required to stabilize the $70 \mathrm{wt}$. \% aqueous suspensions of monolithic $\mathrm{Al}_{2} \mathrm{O}_{3}$ ceramics.

- $\quad 0.3 \mathrm{wt}$. \% of DOLAPIX CE 64 dispersant is required to stabilize the $70 \mathrm{wt}$. \% aqueous suspensions of composite $\mathrm{Al}_{2} \mathrm{O}_{3}-\mathrm{ZrO}_{2}$ ceramics, composed of 99 wt. $\% \mathrm{Al}_{2} \mathrm{O}_{3}$ and 1 wt. $\% \mathrm{ZrO}_{2}$.

- $0.7 \mathrm{wt}$ \% of DOLAPIX CE 64 dispersant is required to stabilize the $70 \mathrm{wt}$ \% \% aqueous suspensions of composite $\mathrm{Al}_{2} \mathrm{O}_{3}-\mathrm{ZrO}_{2}$ ceramics, composed of $95 \mathrm{wt}$. $\% \mathrm{Al}_{2} \mathrm{O}_{3}$ and $5 \mathrm{wt}$. $\% \mathrm{ZrO}_{2}$

- $1 \mathrm{wt}$ \% of DOLAPIX CE 64 dispersant is required to stabilize $70 \mathrm{wt}$. \% aqueous suspensions of composite $\mathrm{Al}_{2} \mathrm{O}_{3}-\mathrm{ZrO}_{2}$ ceramics, composed of $90 \mathrm{wt} . \% \mathrm{Al}_{2} \mathrm{O}_{3}$ and $10 \mathrm{wt} . \% \mathrm{ZrO}_{2}$.

- Apparent viscosity and the required amount of Dolapix CE 64 increase with increasing the zirconia content. 
- Green bodies of monolithic $\mathrm{Al}_{2} \mathrm{O}_{3}$ and composite $\mathrm{Al}_{2} \mathrm{O}_{3}-\mathrm{ZrO}_{2}$ ceramics were formed by slip casting process in plaster molds. After drying, the green bodies were sintered at a temperature of $1650^{\circ} \mathrm{C}$.

- $\quad$ SEM-EDS analysis of prepared composite ceramics showed that $\mathrm{ZrO}_{2}$ particles are dispersed in $\mathrm{Al}_{2} \mathrm{O}_{3}$ matrix with some agglomerates of $\mathrm{ZrO}_{2}$, and pores.

- The obtained $c / a$ values ranging from 2.3 to 3.9 indicate that the Langford model is the most appropriate model for the indentation fracture toughness, because this model can be applied to both median and Palmquist crack types.

- By adding $\mathrm{ZrO}_{2}$ nanoparticles in alumina matrix, the hardness has decreased because the hardness of tetragonal zirconia is lower than alumina. Also, the addition of $\mathrm{ZrO}_{2}$ nanoparticles has caused an increase in total porosity, hence lowering the hardness.

- On the other hand, the fracture toughness of alumina matrix has increased by adding $\mathrm{ZrO}_{2}$ nanoparticles as a result of the synergistic effect of transformation toughening and the microstructural changes.

Author Contributions: Conceptualization, L.Ć., I.Ž. and V.M.; Methodology, I.Ž., D.Ć. and L.Ć.; Formal analysis, L.Ć., D.Ć. and V.M.; Investigation, L.Ć., V.M. and D.Ć.; Resources, L.Ć.; Writing—original draft preparation, L.Ć., I.Ž. and D.Ć.; Writing-review and editing, L.Ć., I.Ž., D.Ć. and V.M.; Visualization, I.Ž., L.Ć., D.Ć. and V.M.; Supervision, I.Ž.; Project administration, I.Ž., L.Ć. and D.Ć.; Funding acquisition, L.Ć. All authors have read and agreed to the published version of the manuscript.

Funding: This research was funded by the Croatian Science Foundation under the project Monolithic and composite advanced ceramics for wear and corrosion protection (WECOR) (IP-2016-06-6000).

Acknowledgments: The authors would like to thank the Rea Veseli, Master of Applied Chemistry for proofreading the English language.

Conflicts of Interest: The authors declare no conflict of interest.

\section{References}

1. Majić, M.; Ćurković, L. Fracture Toughness of Alumina Ceramics Determined by Vickers Indentation Technique. Mater. Test. 2012, 54, 228-232. [CrossRef]

2. Moraes, M.C.C.; Elias, C.N. Mechanical properties of alumina-zirconia composites for ceramic abutments. Mat. Res. 2004, 7, 643-649. [CrossRef]

3. Ramesh, S.; Siah, L.F.; Nor Azmah, A.K. Sintering behaviour of slip-cast $\mathrm{Al}_{2} \mathrm{O}_{3}-\mathrm{Y}$-TZP composites. J. Mater. Sci. 2000, 35, 5509-5515. [CrossRef]

4. Piconi, C.; Maccauro, G. Review: Zirconia as a ceramic biomaterial. Biomaterials 1999, 20, 1-25. [CrossRef]

5. Sommer, F.; Landfried, R.; Kern, F.; Gadow, R. Mechanical properties of zirconia toughened alumina with 10-24vol\% 1Y-TZP reinforcement. J. Eur. Ceram. Soc. 2012, 32, 4177-4184. [CrossRef]

6. Kern, F.; Palmero, P.; Marro, F.G.; Mestra, A. Processing of alumina-zirconia composites by surface modification route with enhanced hardness and wear resistance. Ceram. Int. 2015, 41, 889-898. [CrossRef]

7. Malhotra, S.K.; Singh, P.; Thirunavukkarasu, A. Synthesis of alumina-zirconia nanocomposites by sol gel process. Mater. Manuf. Process. 2006, 21, 652-657. [CrossRef]

8. Sarraf, H.; Herbig, R.; Maryška, M. Fine-grained $\mathrm{Al}_{2} \mathrm{O}_{3}-\mathrm{ZrO}_{2}$ composites by optimization of the processing parameters. Scr. Mater. 2008, 59, 155-158. [CrossRef]

9. Kern, F.; Palmero, P. Microstructure and mechanical properties of alumina $5 \mathrm{vol} \%$ zirconia nanocomposites prepared by powder coating and powder mixing routes. Ceram. Int. 2013, 39, 673-682. [CrossRef]

10. Khan, A.U.; Haq, A.U.; Mahmood, N.; Ali, Z. Rheological studies of aqueous stabilised nano-zirconia particle suspensions. Mater. Res. 2012, 15, 21-26. [CrossRef]

11. Majić Renjo, M.; Lalić, M.; Ćurković, L.; Matijašić, G. Rheological properties of aqueous alumina suspensions. Materwiss. Werksttech. 2012, 43, 979-983. [CrossRef]

12. Tallon, C.; Limacher, M.; Franks, G.V. Effect of particle size on the shaping of ceramics by slip casting. J. Eur. Ceram. Soc. 2010, 30, 2819-2826. [CrossRef] 
13. Reed, J.S. Principles of Ceramics Processing, 2nd ed.; John Wiley \& Sons Inc.: New York, NY, USA, 1995; pp. 154-196.

14. Prakash Rao, S.; Tripathy, S.S.; Raichur, A.M. Dispersion studies of sub-micron zirconia using Dolapix CE 64. Coll. Surf. Physicochemi. Eng. Asp. 2007, 302, 553-558.

15. Binner, J.G.P.; McDermott, A.M. Rheological characterisation of ammonium polyacrylate dispersed, concentrated alumina suspensions. Ceram. Int. 2006, 32, 803-810. [CrossRef]

16. Holmberg, K. Handbook of Applied Surface and Colloid Chemistry, 1st ed.; John Wiley \& Sons: Chichester, UK, 2002; pp. 57-70.

17. Karimian, H.; Babaluo, A.A. Effect of polymeric binder and dispersant on the stability of colloidal alumina suspensions. Iran Polym. J. 2006, 15, 879-889.

18. Shojai, F.; Pettersson, A.B.A.; Mäntylä, T.; Rosenholm, J.B. Electrostatic and electrosteric stabilization of aqueous slips of $3 \mathrm{Y}-\mathrm{ZrO}_{2}$ powder. J. Eur. Ceram. Soc. 2000, 20, 277-283. [CrossRef]

19. Singh, B.P.; Bhattacharjee, S.; Besra, L.; Sengupta, D.K. Electrokinetic and adsorption studies of alumina suspensions using Darvan C as dispersant. J. Colloid Interface Sci. 2005, 289, 592-596. [CrossRef]

20. Tsetsekou, A.; Agrafiotis, C.; Leon, I.; Milias, A. Optimization of the rheological properties of alumina slurries for ceramic processing applications Part II: Spray-drying. J. Eur. Ceram. Soc. 2004, 21, 493-506. [CrossRef]

21. Briscoe, B.J.; Khan, A.U.; Luckham, P.F. Optimising the dispersion on an alumina suspension using commercial polyvalent electrolyte dispersants. J. Eur. Ceram. Soc. 1998, 18, 2141-2147. [CrossRef]

22. Vukšić, M.; Žmak, I.; Ćurković, L.; Ćorić, D. Effect of Additives on Stability of Alumina-Waste Alumina Suspension for Slip Casting: Optimization Using Box-Behnken Design. Materials 2019, 12, 1738. [CrossRef]

23. Sever, I.; Žmak, I.; Ćurković, L.; Švagelj, Z. Stabilization of Highly Concentrated Alumina Suspensions by Different Dispersants. Trans. FAMENA 2018, 42, 61-70. [CrossRef]

24. Chou, K.; Lee, L. Effect of Dispersants on the Rheological Properties and Slip Casting of Concentrated Alumina Slurry. J. Am. Ceram. Soc. 1989, 72, 1622-1627. [CrossRef]

25. Guo, L.C.; Zhang, Y.; Uchida, N.; Uematsu, K. Adsorption Effects on the Rheological Properties of Aqueous Alumina Suspensions with Polyelectrolyte. J. Am. Ceram. Soc. 2005, 81, 549-556. [CrossRef]

26. Majić Renjo, M.; Ćurković, L.; Andrić, I. Preparation of stable suspensions for slip casting of alumina zirconia composite. In Proceedings of the 4th International Scientific and Expert, Technique, Education, Agriculture \& Management-TEAM 2012 Conference, Slavonski Brod, Croatia, 17-19 October 2012; Živić, M., Galeta, T., Eds.; Strojarski fakultet: Slavonski Brod, Croatia, 2012; pp. 81-84.

27. Moreno, R.; Salomoni, A.; Stamenkovic, I. Influence of slip rheology on pressure casting of alumina. J. Eur. Ceram. Soc. 1997, 17, 327-331. [CrossRef]

28. Chinn, R.E. Ceramography: Preparation and Analysis of Ceramic Microstructures, 1st ed.; ASM International: Materials Park, OH, USA, 2002; pp. 35-67.

29. Ćorić, D.; Majić Renjo, M.; Ćurković, L. Vickers indentation fracture toughness of Y-TZP dental ceramics. Int. J. Refract. Met. Hard Mater. 2017, 64, 14-19. [CrossRef]

30. Casellas, D.; Nagl, M.M.; Llanes, L.; Anglada, M. Microstructural coarsening of zirconia-toughened alumina composites. J. Am. Ceram. Soc. 2005, 88, 1958-1963. [CrossRef]

31. Jindal, P.C. A New Method for Evaluating the Indentation Toughness of Hardmetals. Crystals 2018, 8, 197. [CrossRef]

32. Şakar-Deliormanli, A.; Güden, M. Microhardness and fracture toughness of dental materials by indentation method. J. Biomed. Mater. Res. Part B Appl. Biomater. 2006, 76, 257-264. [CrossRef]

33. Anstis, G.R.; Chantikul, P.; Lawn, B.R.; Marshall, D.B. A critical evaluation of indentation techniques for measuring fracture toughness: I, direct crack measurements. J. Am. Ceram. Soc. 1981, 64, 533-538. [CrossRef]

34. Sergejev, F.; Antonov, M. Comparative study on indentation fracture toughness measurements of cemented carbides. Proc. Est. Acad. Sci. Eng. 2006, 12, 388-398.

35. Niihara, K.; Morena, R.; Hasselman, D.P.H. Evaluation of $\mathrm{K}_{\mathrm{IC}}$ of brittle solids by the indentation method with low crack-to-indent ratios. J. Mater. Sci. Lett. 1982, 1, 13-16. [CrossRef] 
36. Roberts, O.; Lunt, A.J.G.; Ying, S.; Sui, T.; Baimpas, N.; Dolbnya, I.P.; Parkes, M.; Dini, D.; Kreynin, S.M.; Neo, T.K.; et al. A Study of Phase Transformation at the Surface of a Zirconia Ceramic. In World Congress on Engineering, WCE 2014, Proceedings of the World Congress on Engineering, London, UK, 2-4 July 2014; Ao, S.I., Gelman, L., Hukins, D.W.L., Hunter, A., Korsunsky, A.M., Eds.; Newswood Limited: Hong Kong, China, 2014; Volume 2, pp. 1173-1177.

37. Liu, W.C.; Wu, D.; Li, A.D.; Ling, H.Q.; Tang, Y.F.; Ming, N.B. Annealing and doping effects on structure and optical properties of sol-gel derived $\mathrm{ZrO}_{2}$ thin films. Appl. Surf. Sci. 2002, 191, 181-187. [CrossRef]

38. Manjula, S.; Mahesh Kumar, S.; Raichur, A.M.; Madhu, G.M.; Suresh, R.; Lourdu Anthony Raj, M.A. A sedimentation study to optimize the dispersion of alumina nanoparticles in water. Cerâmica 2005, 51, 121-127. [CrossRef]

39. Pabst, W.; Gregorová, E.; Malangré, D.; Hostaša, J. Elastic properties and damping behavior of alumina-zirconia composites at room temperature. Ceram. Int. 2012, 38, 5931-5939. [CrossRef]

40. Moazzam Hossen, M.; Chowdhury, F.U.Z.; Gafur, M.A.; Abdul Hakim, A.K.M.; Belal Hossen, M. Effect of Zirconia Substitution on Structural and Mechanical Properties of ZTA Composites. IOSR J. Mech. Civ. Eng. 2014, 11, 01-07. [CrossRef]

41. Naglieri, V.; Palmero, P.; Montanaro, L.; Chevalier, J. Elaboration of Alumina-Zirconia Composites: Role of the Zirconia Content on the Microstructure and Mechanical Properties. Materials 2013, 6, 2090-2102. [CrossRef]

42. Ahmad, I.; Islam, M.; Habis, N.A.; Parvez, S. Hot-Pressed Graphene nanoplatelets or/and Zirconia Reinforced Hybrid Alumina Nanocomposites with Improved Toughness and Mechanical Characteristics. J. Mater. Sci. 2018. [CrossRef]

43. Matsumoto, Y.; Hirota, K.; Yamaguchi, O. Mechanical Properties of Hot Isostatically Pressed Zirconia-Toughened Alumina Ceramics Prepared from Coprecipitated Powders. J. Am. Ceram. Soc. 1993, 76, 2677-2680. [CrossRef]

44. Takano, Y.; Ozawa, T.; Yoshinaka, M.; Hirota, K.; Yamaguch, O. Microstructure and Mechanical Properties of $\mathrm{ZrO}_{2}(2 \mathrm{Y})$-Toughened $\mathrm{A1}_{2} \mathrm{O}_{3}$ Ceramics Fabricated by Spark Plasma Sintering. J. Mater. Synth. Process. 1999, 7, 107-111. [CrossRef]

45. Tang, Y.; Yonezu, A.; Ogasawara, N.; Chiba, N.; Chen, X. On radial crack and half-penny crack induced by Vickers indentation. Proc. R. Soc. A Math. Phys. Eng. Sci. 2008, 464, 2967-2984. [CrossRef]

46. Elsaka, S.E.; Elnaghy, A.M. Mechanical properties of zirconia reinforced lithium silicate glass-ceramic. Dent. Mater. 2016, 32, 908-914. [CrossRef] [PubMed] 